\title{
Analysis of Factors For Increasing Income Tax in Motor Vehicles in UPT PPD (Technical Implementing Unit of Regional Revenue Management) in Siantar
}

\author{
Dona Hendrianto Damanik ${ }^{1}$, Marlon Sihombing ${ }^{2}$, Hamdani Harahap ${ }^{3}$ \\ ${ }_{1,2,3}$ University of Sumatera, Indonesia \\ hendridmk22@gmail.com
}

\begin{abstract}
In principle, motor vehicle tax plays a role in providing PAD for the North Sumatra Provincial Government. In this connection, the tax target must be increased every year and contribute to development in North Sumatra. To optimize the potential for motor vehicle tax revenue, it is necessary to know the factorsin increasing motor vehicle tax revenue at the UPT PPD (Technical Implementation Unit for Regional Revenue Management). ThereforeThe formulation of the problem in this study is as follows: "What factors influence itincrease in motor vehicle tax revenue at UPT PPD (Technical Implementation Unit for Regional Revenue Management) Pematang Siantar based onThe policy implementation approach is based on the formulation of the Van Meter and Van Horn models called A Model of the Policy Implementation. In this study the authors used a descriptive method with a research focus, namely the Analysis of Factors Factors for Increasing Motor Vehicle Tax Revenues at UPT PPD (Technical Implementation Unit for Regional Income Management) Pematang Siantar ". The research site is an area whose location is used to obtain the data required for this research activity. The research results show thatMotor Vehicle Tax revenue factors, such as culture, communication, information, good cooperation with personnel and the use of renewable technology and so on, greatly affect the increase in Motor Vehicle Tax revenue at UPT Samsat Pematang Siantar.
\end{abstract}

Keywords taxes implementation; local income

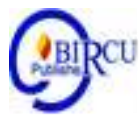

\section{Introduction}

The presence of the provision of regional autonomy implies the emergence of authority and obligation for regions to carry out various government activities more independently. To realize these goals, namely independent government, regional governments need a large enough source of funds, these sources of funds play an important role in supporting the continuity of government and society itself. This source of funds can be obtained through community participation in various forms, one of which is taxes. As a rule of law, everything concerning taxes has been stipulated in the 1945 Constitution Article 23 A which reads: "Taxes and other levies of a compelling nature for the needs of the state are regulated by law".

The imposition of Motor Vehicle Tax on PAD is based on the provisions of Law Number 28 of 2009, articles 3-8. The application of motor vehicle tax in a province is based on the relevant provincial regional regulations which are the operational legal basis for the technical implementation of motor vehicle tax imposition and collection in the region of the province concerned as well as the governor's decree regulating motor vehicle 
tax as a rule for implementing regional regulations on taxes motorized vehicles in the said Province.

The Regional Tax and Retribution Management Agency of North Sumatra Province claims that the realization of regional tax revenue, namely Motor Vehicle Tax (PKB), which was collected until December 31, 2019, has reached $101.38 \%$ or IDR 2.013 trillion from the target in the 2019 APBD Amendment of IDR 1.986 trillion.

Transfer of Motor Vehicle Title Fee (BBNKB) reaches $96 \%$ or Rp. 1,347 of the target of Rp 1,404 trillion, Motor Vehicle Fuel Tax (BBKB) 102.23\% of the target of Rp 760 billion, surface water tax of $121.51 \%$ of the target of Rp 208 billion.

Whereas in the last three years, namely 2017 to 2019 Kota Pematang Siantar, tax revenue from motorized vehicles in Pematang Siantar at the UPT PPD (Office of the Technical Implementation Unit for Regional Revenue Management) Pematang Siantar amounted to more than IDR 275 billion. Even other types of tax revenue, if calculated starting from PKB, BBN KB, APU tax, PKB and KBN KB fines for 2019 realized in the figure of Rp. 93 billion more.

The high tax revenue through UPT Pematang Siantar in 2019 will be used to finance development and public services for the community in Pematang Siantar City. Tax collection and regulations that regulate it are borne by taxpayers to increase regional income, but on the other hand, taxes can also hinder the development of the regional economy if tax collection is excessive or withdrawn improperly according to the predetermined tax rate. Based on the above background, the researcher took the title Analysis of Factors - Factors for Increasing Motor Vehicle Tax Revenue at the UPT PPD (Technical Implementation Unit for Regional Revenue Management) Pematang Siantar.

\section{Review of Literature}

\subsection{Elements of Public Policy Implementation}

The elements of policy implementation that absolutely must exist are: "(1) an implementing element (implementor), (2) a program to be implemented, (3) target groups (Abdullah, 1988: 11). The two initial perspectives in the implementation study are based on the question of the extent to which implementation is separate from policy formulation, namely whether a policy is made by the center and implemented by the regions (top-down) or is the policy made by involving aspirations from below including those who will be the implementers (bottom). -up). In fact, this problem is only part of a broader problem, namely how to identify the images of a very complex process, from various spaces and times, as well as the various actors involved in it.

According to Abdullah (1998), he explained that the top down approach was originally the approach most widely used by public policy makers, although in the future there were also weaknesses in this approach which led to debates that resulted in a new approach called the bottom up approach. In a top-down approach, policy implementation is carried out in a centralized manner and starts from the actors at the central level, and decisions are also made at the central level. This approach also starts from the perspective that political decisions (public policies) that have been determined by policy makers must be carried out by administrators or bureaucrats at a lower level. The essence of this approach can simply be understood as the extent to which the actions of the implementers (administrators and bureaucrats) are in accordance with the procedures and goals outlined by policy makers at the central level. So to understand the second approach, namely bottom up, in essence, starting on the same assumptions and understanding them is the reverse of what we understand in the top down approach. In implementation studies the 
pretension to develop a general theory of implementation (grand theory) that can apply to all cases, in all places and times, is almost impossible to achieve, because what is developed will be nothing more than a theory of "action" or theory of "implementing" not a theory of Policy Implementation.

According to George Charles Edwards III in Herabudin (2016)that the main problem of public administration is "lack attention to implementation that without effective implementation the decision of policymakers will not be carried out successfully". Communication regarding how policies are communicated to the organization and / or the public, the availability of resources to implement the policies, attitudes, and responses from the parties involved and how the organizational structure of policy implementation are:

1) Communication, the success of the policy requires that implementors know what to do. What are the goals and objectives of the policy (target group) so that it will reduce distortions in implementation. If the goals and objectives of a policy are not clear or even completely unknown to the target group, then there is likely to be resistance from the target group.

2) Resources, although the content of the policy has been clearly communicated and consistent, but if the implementor lacks the resources to implement it, the implementation will not be effective. These resources can be in the form of human resources, namely the implementor competition, and financial resources. Resources are an important factor for effective policy implementation. Without the resources, policies only stay on paper, become documents.

3) Disposition, is the character and characteristics or attitudes possessed by the implementor such as commitment, honesty, democratic nature. If the implementor has a good disposition, then he will be able to carry out policies properly as desired by policy makers. When the implementor has a different character or perspective from the policy maker, the policy implementation process will also be ineffective.

4) The bureaucratic structure in charge of implementing policies has a significant influence on policy implementation. One of the important structural aspects of any organization is the existence of standard operating procedures or SOPs. SOPs serve as guidelines for every implementor in action. Organizational structures that are too long will tend to weaken supervision and lead to red tape, namely complicated and complex bureaucratic procedures. This in turn causes the organization's activities to be inflexible.

\subsection{Constraints / Barriers to Policy Implementation}

Policy implementation is not a simple process, but it is very complex and intricate and is a dynamic process, the end result cannot be predicted only from the availability of the completeness of the program. The task of implementing policies should be taken into account. Sometimes in the practice of the public policy process, there is an assumption that implementation will run automatically after successful policy formulation is carried out. Nugroho (2014) states that implementation myopia often occurs in Indonesia, one of which is "So far we think that if the policy has been made, the implementation will" go by itself ". Where most of the resources are spent on planning, even though it is the policy implementation stage that should consume the most resources, not the other way around.

Implementation functions to establish a link that allows policy objectives to be realized, so that they become what is known as the work or achievement of the government. However, in practice what happens is a failure in implementation because even if it has been carefully calculated, it does not mean that the implementation process will be successful. Problems often arise because the reality on the ground is not as 
predicted. Walter William mentioned the implementation difficulties as follows: "The most pressing implementation problem is that of moving from a decision to operation in such way that what it is put into place bears a reasonable resemblance to the decision and is fuctioning well in its that of the difficulty. of bringing the gap between policy decision and workable field operations "(Pamudji, 2007). Interpreting decisions into appropriate operational actions is not as easy as one might think. Will it work properly later or not. This has become one of the difficulties in the policy implementation process.

Rochyati (2012), provides an explanation in general that failure in an implementation process (Unimplemented Policy \& Poorly Implemented Policy) can be caused by:

1. Unimplemented Policy:

a. Policies are only political in nature and are not really meant to be implemented (therefore they are not accompanied by implementing regulations, and do not even appoint an agency responsible for implementing them). Policies like this are generally only to accommodate the demands of opposing interest groups.

b. Difficulty interpreting policies in the form of operational activities, whether policy objectives are too utopian, not in accordance with field conditions, or because of constraints in the field that limit alternative actions.

2. Poorly Implemented Policy

Weak implementation capacity of the implementers. This can happen because:

a. The implementation structure is not structured effectively

b. Conflict of interpretation of program objectives between actors, including administrators, field officers, and target groups

c. Conflict of interest between actors, including administrators, field officers, and target groups

d. Lack of capacity and capability of implementers (inappropriate / appropriate human resources)

e. Lack of organizational capacity and capability of the implementing institutions

f. Weak implementation management

g. Lack of risorsis (resources such as budget, tools). (Rochyati, 2012)

From the description of the factors that can become obstacles in the implementation process, it can be concluded that the success of implementation (Rochyati, 2012) will depend heavily on:

1. The logic of the policy itself

2. Executing ability

3. Availability of the required resources

4. Good implementation management

5. The environment in which the policy is implemented

\subsection{Definition of Tax}

The notion of tax itself has different dimensions. According to Siahaan (2011), tax is a levy that is the government's preogative right, the levy is based on law, the collection can be forced on the tax subject for which there is no direct remuneration that can be demonstrated for its use. From this definition, it can be concluded that the state (government) is entitled to collect taxes. Taxes are collected based on laws and implementing regulations which can be imposed on the tax subject. In paying taxes, it cannot be shown that there are individual contra performance from the government. Meanwhile, according to Rochmat Soemitro in his book Basic - Basis of Tax Law and Income Tax. 
Tax is a compulsory levy paid by the people to the state and will be used for the benefit of the government and the general public. People who pay taxes will not feel the benefits of taxes directly, because the tax is used for public purposes, not for personal gain. Taxes are one source of government funds for development, both the central and regional governments. Tax collection can be forced because it is carried out according to the law. (Siregar et al, 2019)

PJA Adriani argues that taxes are public contributions to the state (which can be enforced) which are owed by those who are obliged to pay them according to general regulations (Laws) with no return that can be directly appointed and whose use is to finance general expenses. Due to the state's duty to organize the government. Meanwhile, according to the economist NJ Fieldmann in his book entitled De overheidsmiddelen van Indonesia (1949) provides a limitation that taxes are an achievement that is forced unilaterally and owes to the authorities (according to the norms that he has established in general), without any contra-achievement, and only - the eye is used to cover general expenses.

Tax is an obligation to hand over part of wealth to the state treasury due to circumstances, events and actions that give a certain position, but not as a punishment, according to regulations established by the government and can be enforced and has sanctions but there is no direct reciprocal service from the state, tax. necessary to maintain the general welfare. Taxes as a manifestation of state obligations, it is emphasized that the placement of burdens on the people, such as taxes, levies and others, must be stipulated by law. Regional Original Revenue (PAD), which includes regional taxes and levies, is one of the sources of financing for government administration and regional development in order to increase and equalize the welfare of the community.

Taxes are a source of state revenue used to finance government spending and development. One of the taxes that the government imposes on its people is income tax including income from dissability. (Hendayana et al. 2021)

\section{Research Methods}

In this study the authors used a descriptive method (Descriptive Research) with a qualitative approach or by using descriptive analysis. As forThe data analysis technique used in this research is analysis using interactive models (interactive models of analysis).

\section{Results and Discussion}

The policy implementation approach in this study uses the Van Meter and Van Horn model formulations called A Model of the Policy Implementation. The process of implementing tax revenue as a provision of Law Number 28 of 2009 from motor vehicle taxpayers at the UPT Pematang Siantar Regional Revenue Management is an abstraction or performance of a policy understanding practice which is basically deliberately carried out to achieve high performance results of policy implementation, namely exceeding the target of tax revenue at UPT Pematang Siantar Regional Revenue Management which is related in the relationship of various variables. This model assumes that the policy implementation runs linearly from the implementing decision that the high performance of tax revenue at the UPT Pematang Siantar Regional Revenue Management policy is influenced by several variables. (Agustino, 2012). Among others: 


\subsection{Size and Policy Objectives}

The performance of policy implementation can be measured the level of success if the size and objectives of the policy are in accordance with the socio-culture at the level of implementing the policy. When policy measures or policy objectives are too standard to be implemented at the citizen level, realizing the policy is quite difficult. The implementation of the tax revenue policy at the UPT Pematang Siantar Regional Revenue Management is an effort unity. These efforts are carried out continuously so that the motor vehicle tax revenue tarcarried out to increase Motor Vehicle Tax (PKB) revenue originating from the commget is achieved. The implementation is divided into several parts, namely:

1. The service procedure for collecting motor vehicle taxes, among others, reduces the time needed to settle motor vehicle certificates more quickly.

2. Provision of service facilities, such as providing Mobile Samsat (SAMKEL), Samsat outlets and others.

3. Recollecting data on motor vehicle tax subjects and objects, among others by carrying out a motor vehicle tax census by visiting taxpayers' homes who are still in arrears for motor vehicle taxes.

4. Improving the quality of the apparatus through education and training, with the increase in the quality of the apparatus it is hoped that in terms of service or calculating taxes and regarding the regulations of employees on duty it will be better.

5. Conduct regular raids in accordance with the socio-cultural conditions of the community in accepting policies. The raids were carried out by 3 related elements, namely: elements of the UPT Samsat Kota Pematang Siantar, the Police and Jasa Rahaja.

Then seen from the supporting factors for the size and objectives of the policy, it is also based on the growth in the number of motorized vehicles in Pematang Siantar City, which in 2018 amounted to 16,332 units of vehicles, with details of 1,297 Passenger Cars, 78 units of Bus Cars, 821 Units of Cargo Cars, Motorcycles. 14,136 Units. Whereas in 2019 the number of motorized vehicles was 27,985 units, with details of Passenger Cars 2,977 Units, Bus Cars 148 units, Cargo Cars 1732 Units, Motorcycles 23,128 units (list attached).

When viewed from the data above, the growth of motorized vehicles in Siantar City from 2018 to 2019 has increased by 11,653 units. This is because individual ownership is increasing as an impulse to need. The increase in the number of motorized vehicles in Pematang Siantar City can also be seen by the increasing sales transactions of motorized vehicles, both two-wheeled and four-wheeled, in offices and showrooms that are contained in dealerships and serial letters that are more than two letters behind the vehicle plate number. In addition, the development of plantation industries and other resources that are increasingly developing makes it possible to increase their transportation fleet to support their operational activities, both two-wheeled and four-wheeled. In addition, it has become a habit for the community to be interested, especially in two-wheeled vehicles to support their mobility in Pematang Siantar City. Likewise, as one of the objectives of tax revenue, namely on public road facilities that continue to improve.

In order to improve public services, especially in the land transportation sector, the Pematang Siantar City government has improved the quality of public roads, thus encouraging someone, in this case the community, to own both two-wheeled and fourwheeled motorized vehicles. Thus the value of PKB / BBNKB revenues will increase. This can be seen from the target charged to the Pematang Siantar Technical Implementation Unit (UPT PPD) in 2018 amounting to Rp. 82,583,376,190 and can be appealed for Rp. 93,335,542,649, - or $113.02 \%$. Whereas in 2019 the Pematang Siantar Technical Implementation Unit for Regional Revenue Management (UPT PPD) will be charged with 
a target of Rp. 89,800,892,369 and can be realized as much as Rp. 93,430,160,317, or $117.01 \%$. (list attached)

The things mentioned above are in accordance with the interview that the author conducted with the HeadThe Technical Implementation Unit (UPT) for Regional Revenue Management (PPD) Pematang Siantar, namely Mrs. Herliene Yudhah Altius, S.STP, M.Si and the Head of PKB / BBN-KB (Motor Vehicle Tax / Motor Vehicle Name Transfer Fee), namely Mr. Dr. Drs. Victor Lumbanraja, MAP, MSP.

\subsection{Resource}

The success of the policy implementation process really depends on the ability to use the available resources. Implementation demands quality human resources in accordance with the work indicated by the policy through their competencies and capabilities. UPT PPD Pematang Siantar has 44 ASN people (data attached). With existing personnel, it is expected to be able to serve taxpayers. The implementors of taxpayer services with computerized system resources at the UPT PPD Pematang Siantar. With an online computerized system at the UPT PPD Pematang Siantar office, services to taxpayers in managing STNK, BPKB, TNK, PKB / BBNKB and SWDKLLJ payments can be streamlined. If previously the completion of motor vehicle certificates took 7 (seven) days to several days, then for now it can be completed in one or two days. The number of computer devices to support services at UPT PPD Pematang Siantar is 30 computers with details in 12 units of service, 6 units of administration or administration, 3 units each of Gerai Raya and Mandoge outlets and 3 Mobile Buses owned by UPT PPD. Pematang Siantar as many as 6 units. (attached data) Gerai Raya and Gerai Mandoge each have 3 units and on 3 Mobile Buses owned by UPT PPD Pematang Siantar as many as 6 units. (attached data) Gerai Raya and Gerai Mandoge each have 3 units and on 3 Mobile Buses owned by UPT PPD Pematang Siantar as many as 6 units. (attached data)

The supporting factor is the satisfaction of taxpayers in carrying out their obligations which can be fulfilled by the UPT Pematang Siantar Regional Revenue Management. With the fulfillment of taxpayer satisfaction, it is hoped that it can increase their awareness of not neglecting the obligation to pay taxes. This condition is a hope for people to diligently pay taxes, especially PKB / BBNKB.

Based on the results of an internal survey conducted by the BPPRDSU Regional Income Development and Control Sector at UPT PPD Pematang Siantar, the Community Satisfaction Index (IKM) for services provided to taxpayers obtained an IKM value of 82.4, with this figure it can be seen that the quality UPT PPD Pematang Siantar services as a whole get a "B" score or with a "Good" performance. The things mentioned above are in accordance with the interview that the author conducted with the Head of the Regional Revenue Development and Control Division, namely Mr. Syaiful Bahri, S.Sos, MSP and the Head of the Revenue and Determination Section at the UPT Pematang Siantar Regional Revenue Management, namely Drs. Abdul Gani Lubis.

\subsection{Implementing Agent Characteristics}

The focus of attention on implementing agencies includes formal organizations and informal organizations that will be involved in implementing public policies. This is very important because the performance of policy implementation will be very much influenced by characteristics that are very precise and suitable with the implementing agencies.

In the fragmentation aspect, it was found that the services of the UPT Pematang Siantar Regional Revenue Management were said to be free of pressures from outside the bureaucratic units, such as the legislature, executive officials, and interest groups that 
interfere with the running of the Pematang Siantar Regional Revenue Management UPT services. From the results of observations and interviews that indicate that the situation is already good, thus the fragmentation aspect has been running well.

The supporting factor is the aspect of Standard Operational Procedure (SOP) which found that the services of the UPT Pematang Siantar Regional Revenue Management already have an SOP (SOP data attached), the implementation of Samsat Corner services so far is based on adjusting the Standard Operational Procedure at the UPT Pematang Siantar Regional Revenue Management, with Thus it can be concluded that the Standard Operational Procedure aspect can run well even though it is still not perfect, as there are many differences among them are from the aspect of facilities and infrastructure of UPT services, Regional Revenue Management, Pematang Siantar, which is much smaller when compared to Samsat in other North Sumatra areas.

The things mentioned above are in accordance with the interview that the author did with the Administrative Unit for Administration of the Regional Revenue Management Unit of Pematang Siantar, namely Mr. Abd. Somad, SE and Mr. Obed Alfredo Manurung as taxpayers.

\subsection{Attitudes / tendencies (Disposition) of the implementers}

The attitude of acceptance or rejection from the implementer will greatly affect the success or failure of the performance of public policy implementation. This is very possible because the policies implemented are not the result of the formulation of local residents who are very familiar with the problems and problems they feel. That the attitude I tendency aspect requires internal supervision at the UPT Pematang Siantar Regional Revenue Management, supervision of the implementation of tasks by employees that is carried out periodically, so that one form of attitude such as employees who are late or absent on working days as well as services to taxpayers can be given sanctions. so that it affects the quality and comfort of taxpayers.

This is supported by the implementation of work evaluation factors carried out through informants who are at the service of the UPT Pematang Siantar Regional Revenue Management, besides that the work evaluation of all the techniques carried out must convey this information through the media available at the UPT Siantar Regional Revenue Management, in order to improve service accountability UPT Pematang Siantar Regional Revenue Management and performance quality.

The things mentioned above are in accordance with the interview that the author did with the Head of the UPT PPD (Pematang Siantar, namely the Technical Implementation Unit for Regional Revenue Management Mrs. Herliene Yudhah Altius, S.STP, M.Si.

\subsection{Interorganizational Communication and Implementing Activities}

Coordination is a powerful mechanism for implementing public policies. The better the communication coordination between the parties involved in an implementation process, then the assumption is that errors will be very small to occur, and vice versa. Providing services through regulatory decisions properly without any conflict of opinion between orders and fellow officers, as a guarantee of service to be provided to service users (taxpayers).

As a supporting factor is the clarity of communication between UPT service providers Regional Revenue ManagementPematang Siantar by providing security guarantees for the current position and position of services to service users (taxpayers) by providing a receipt for submission of documents from the public, providing a receipt for the delivery of service products that do not overlap and confuse motor vehicle taxpayers. 
Besides that, UPT service providers Regional Revenue ManagementPematang Siantar maintains consistent communication between providers and service users, this consistency can be seen in several aspects such as consistency of requirements, procedures / mechanisms, timeframe and service schedule, and other information. The communication carried out by service providers at UPT PPD Pematang Siantar consisting of ASN BPPRD, Jasa Rahaja, Police and Bank of North Sumatra is to:

1. Samsat advisory team meeting at UPT PPD Pematang Siantar.

2. Coordination with the Bank regarding motor vehicle tax revenue.

3. Motorized Vehicle Intensification, namely by doing rajia with related elements.

The things mentioned above are in accordance with the interview that the author did with the Administrative Section of the UPT Regional Revenue Management Unit of Pematang Siantar, namely Mr. Abd. Somad, SE.

\subsection{Economic, Social and Political Environment}

By increasing $\mathrm{PKB} / \mathrm{BBNKB}$ receipts and the rapid growth of various types of motorized vehicles, many companies enter their motorized vehicles into Pematang Siantar City to support their operational activities. In addition, there is a growing public interest in buying various types of motorized vehicles which are considered to be the most effective means of transportation.

With supporting factors the external environment also contributes to the success of the established public policies. The unfavorable social, economic and political environment can be the culprit for the failure of the performance of policy implementation. The addition of various types and brands of motor vehicles based on field observations, the types and brands of motorized vehicles are increasing and varying. Recently, the brands and types of two-wheeled motorized vehicles that are produced in an affordable way with affordable installment and Door Prize mechanisms and for four-wheeled vehicles by other producing countries such as China and Korea have made more choices to own / buy motorized vehicles.

\section{Conclusion}

Based on the above discussion, it can be concluded, among others:

1. The mechanism for receiving and collecting Motor Vehicle Tax (PKB) by the UPT (Technical Implementing Unit) Pematang Siantar's Regional Revenue Management (PPD) runs quite well, the suitability also provides good services to the taxpayers' community.

2. Thus with the implementation of the PKB / BBN-KB collection it has been going well with the division of tasks in their respective fields, even though there needs to be improvements so that they do not overlap and understand the SOP (Standard Operating Procedure) and Tupoksi (Main duties and functions).

3. Other supporting factors in Motor Vehicle Tax revenue, such as culture, communication, information, good cooperation with personnel and the use of renewable technology and so on, greatly affect the increase in Motor Vehicle Tax revenue at UPT Samsat Pematang Siantar.

4. Efforts to increase that have been made by UPT (Technical Implementation Unit) Pematang Siantar Regional Revenue Management (PPD) are good enough so that this service is balanced with the increase in Motor Vehicle Tax revenue at UPT PPD (Technical Implementation Unit for Regional Revenue Management) Pematang Siantar. 


\section{References}

Afrizal. (2015). Metode Penelitian Kualitatif: Sebuah Upaya Mendukung Penggunaan Penelitian Kualitatif dalam Berbagai Disiplin Ilmu. Jakarta: PT Raja Grafindo Persada.

Amelia, Yessy Afriani. (2008). Upaya optimalisasi pelaksanaan pemungutan pajak kendaraan bermotor terhadap pendapatan asli daerah periode 2003-2007 (Studi Kasus di Kantor Samsat Jakarta.Barat). Fakultas Ekonomi dan Bisnis Binus. Jakarta.

Hendayana, Y, et al. (2021). How Perception use of e-Filling Technology Enhance Knowledge of Indonesian Disability Taxpayers and Impact Tax Compliance. Budapest International Research and Critics Institute-Journal (BIRCI-Journal). P. $1687-1696$

Herabudin. (2016). Studi Kebijakan Pemerintah dari Filosofi ke Implementasi. Bandung: CV Pustaka Setia.

Moleong, L. J. (2019). Metodologi Penelitian Kualitatif. Bandung: PT Remaja Rosdakarya. Nugroho, R. (2014). Metode Penlitian Kebijakan. Yogyakarta: Pustaka Pelajar.

Pasolong, H. (2007). Teori Administrasi Publik. Bandung: Alfabeta.

Rochyati (2012), Pendekatan dan teori - teori implementasi. Surabaya: Unair Press.

Siahaan, Pahala, 2011, Pajak dan Retribusi Daerah, Jakarta: Rajawali Pers.

Siregar, R. et al. (2019). The Effect of Corporate Taxpayer Compliance, the Increase of Corporate Taxpayers' Number and Tax Audits on Income Tax Receipts of Article 25 with Taxation Sanctions as a Moderating Variable in KPP Pratama Medan Petisah. Budapest International Research and Critics Institute-Journal (BIRCI-Journal). P. $385-400$ 